INTERACTIVE ARTICLE COVER

RUPKATHA JOURNAL

About the Journal

\begin{tabular}{|c|c|}
\hline \multicolumn{2}{|r|}{ About the Journal } \\
\hline Journal DOI & https://doi.org/10.21659/rupkatha \\
\hline Journal Home & www.rupkatha.com $\oslash$ \\
\hline & Scopus $\triangle$ Web of Science: Emerging Sources Citation Index (ESCI) DOAJ \\
\hline Journal Metrics & CiteScore 2020: 0.2 | SJR 2020: 0.162 | SNIP 2020: 0.193 | JCI 2020: 0.50 \\
\hline \multicolumn{2}{|r|}{ About the Issue } \\
\hline Themed issue & $\begin{array}{l}\text { Volume 4, number 1, } 2022 \text { (January-March) | Contemporary East and } \\
\text { Southeast Asian Literary and Cultural Studies }\end{array}$ \\
\hline Guest Editors & Dr Jeremy de Chavez $\oslash$ \& Dr Zhang Yue, University of Macau, China \\
\hline Issue DOI & https://doi.org/10.21659/rupkatha.v14n1 \\
\hline TOC & https://rupkatha.com/v14n1.php \\
\hline Peer Review & Under the responsibility of the Guest Editors \\
\hline \multicolumn{2}{|r|}{ About the Article } \\
\hline Title & $\begin{array}{l}\text { Pop Song Translations by Rolando Tinio as Script and Subversion of the } \\
\text { Marcos Regime }\end{array}$ \\
\hline Author/s & Niccolo Rocamora Vitug $\otimes$ \\
\hline Affiliation & University of the Philippines, Quezon City, Philippines \\
\hline Author ID & Not available \\
\hline Funding & No funding received. Published free of any charge. \\
\hline Article DOI & https://doi.org/10.21659/rupkatha.v14n1.17 Pages: 1-21 \\
\hline Abstract & https://rupkatha.com/v14n117 \\
\hline Full-text PDF & https://rupkatha.com/V14/n1/v14n117.pdf \\
\hline \multirow[t]{3}{*}{ Article History } & Abstract received: 10 Feb 2021 | Complete article received: 13 June 2021 \\
\hline & Revised article received: 14 Aug 2021 | Accepted: 6 Sept 2021 \\
\hline & First Published: 05 February 2022 \\
\hline Article Impact & Check Dynamic Impact $\square$ \\
\hline Copyright & Aesthetics Media Services \\
\hline Licensing & Creative Commons Attribution Non-Commercial 4.0 \\
\hline
\end{tabular}

This Open Access article is published under a Creative Commons Attribution Non-Commercial 4.0 International License (http://creativecommons.org/licenses/by-nc/4.0/), which permits non-commercial re-use, distribution, and reproduction in any medium, provided the original work is properly cited. For citation use the DOI. For commercial re-use, please contact editor@rupkatha.com. 


\title{
Pop Song Translations by Rolando Tinio as Script and Subversion of the Marcos Regime
}

\author{
Niccolo Rocamora Vitug \\ Faculty at the University of Santo Tomas and PhD Scholar at the College of Music, University of \\ the Philippines, Quezon City, Philippines.
}

\begin{abstract}
Philippine National Artist for Theater and Literature Rolando Tinio was well-known for his translations. Though attention is rightfully given to the theatrical works he translated into Filipino, he is also known to have translated songs. One of the enduring sets of song translations that he made are recorded in the album "Celeste," rendered by the singer and actress Celeste Legaspi. This album was released in 1976, not long after the establishment of the Cultural Center of the Philippines (CCP). Then First Lady Imelda Romualdez Marcos had an interest in the arts, looking at it as something to uphold because it served a function in the vision of the Marcos regime. What I seek to problematize is how the song translations followed a script-in line with the ideas of music theorist Nicholas Cook-based on the said vision. Such a script, according to Michel Foucault, might be the locus of both obedience and subversion. The identification of this script will be done by a reading of a representative pop song translation by Tinio, in the context of other materials that elucidate the script of the time-from the former first couple and one who held a key position in their regime. The reading will be supported by a reading of Tinio's last translation work, that of Nick Joaquin's A Portrait of the Artist as Filipino, which was turned into a musical entitled Ang Larawan.
\end{abstract}

Keywords: music as script, translation, pop songs, Rolando Tinio, Teatro Pilipino, Marcos regime

Rolando S. Tinio, Philippine National Artist for Literature and Theater ${ }^{1}$, was known for being able to do many things. Poet, playwright, director, designer, he even dabbled in songwriting. Gifted with what seems to be genius, it is easy to fall into the trap of revering such a figure. The obverse of this, however, is that it is equally easy to be outright dismissive of such a person. Today, when sharp polarities seem to plague our political life, problems might arise because of such fixed and inflexible positions.

I am all for the freedom of expression but would like to give attention to headlines such as "In 1986, Filipino Writers and Artists Sold Out to a Dictator," which appears on a post on the Medium app (Tan, 2018). The post contains the text of a paid advertisement from January 28, 1986, in support of the reelection bid of despot Ferdinand Marcos ${ }^{2}$. Though I believe in the critical attention that such a headline gives, one might want to take it carefully.

The following is an excerpt from the Medium post which, as mentioned earlier, was quoted 
from a paid advertisement, entitled "Declaration of the Coalition of Writers and Artists for Freedom and Democracy":

The plain and simple fact is that we, as writers and artists, have serious apprehension about the candidates of the opposition. We are apprehensive about the fact that they have nothing to offer than a dubious promise of sincerity and an even more dubious promise to hand government over to an unidentified cadre of advisers. These are no more than niggardly excuses for lack of a coherent program of government.

In view of the crises that threaten the economic security and the cultural serenity of our nation, we can only regard such representation from them as symptomatic of a reluctance to come to grips with reality and an indifference to the need for wisdom and maturity.

As such, this coalition seeks to preserve what has already been achieved in terms of cultural advancement and to proceed further under an enlightened and transformed national leadership equipped to face the pressures of change and advance our national and spiritual progress. We believe that the leadership of President Ferdinand E. Marcos is our only guarantee for survival at this point. ("Declaration," 1986, p. 11)

Clearly, the declaration is not something that I would support given the plunder and the human rights violations of the Marcos administration. However, one might want to consider the milieu of the period, and how particular individuals survived in such a context. The question arises: are there no other ways by which people might work against a despotic administration? Is it all a matter of black and white, then?

The issue of sharp polarities comes into question when figures who risked their lives during the Marcos administration speak for such figures as Tinio. Take for example the words of his friend and former colleague, fellow National Artist Bienvenido Lumbera:

Perhaps the most enduring monument that would glorify Rolando as National Artist is his collected translations from the different periods of theater in the West which he reworked into Tagalog, directed, designed, and found a young audience for. In Philippine theater history, only Rolando took on the labor that, if others were in charge, would require many hands and loads of money. That labor is the organizing of Teatro Pilipino, the building of its repertory through his translations, the training of the acting ensemble that would give life to characters from different times and cultures, the shaping of the productions that responded to the demands of each play, and the prudent allocation of limited resources (budget, actors with their individual quirks, things and tools that needed to be obtained in various places, etc.) As of today, no one has sufficiently measured the extent of the contributions of Rolando's translations to our culture. What we are certain of thus far is that the repertory of Teatro Pilipino is a rich resource of texts which can be revisited by coming generations of creators in theater as they look for plays to study, to train with, and which can be used to fill the hungers of viewers who have their educational, cultural, and spiritual needs ${ }^{3}$. ("Si Tinio, Henyo ng Maraming Sining" [Tinio, A Genius of Many Arts], c2014, p. 172)

Lumbera's estimation, as compared to the Medium headline, is clearly more informed, though it may border on the other end of the spectrum. It is clear from the testimony that Tinio did 
contribute much to the cultural life of the Philippines through translating works from foreign languages and adding these to the repertory of Teatro Pilipino, which used to be the resident theater company of the Cultural Center of the Philippines.

It is well-known that Lumbera was jailed during the imposition of martial law in the country. Hence, such high estimation of someone who did not seem to waver in loyalty to the Marcoses calls much attention. It is from this point that I would like to embark on the explorations in this paper. There must be some kind of useful middle ground wherein we can assess the contributions of people with spotted histories, avoiding immediate and wholesale dismissal.

In this paper, I would like to propose that Tinio's work in poetry and musical theater provides reason for us to reassess his association with the Marcos regime. While not exonerating him for his association, one might explore the spaces in the relationship which might be seen as means to subvert the relationship. The translation work, which comes on the heels of his previous experience with Bagay (which translates to "thing" or "object" in English) poems, might have left spaces wherein creativity and critical thought could flourish. In this sense, Tinio left room for subversion of the Marcos script.

\section{Music as Script and Subversion}

I take for my critical position the ideas of musicologist Nicholas Cook, and Michel Foucault, whose very unusual approach to thinking and life still compels thought to this day. Cook, in his critical approach to classical music, has seen that musical notation is not simply a matter of formal rendition of sounds following the rules of music theory. He has made mention of the concept that music has metaphors that are its foundation-for example, a string quartet has each of the instruments in conversation. Because of this metaphor, composers are led to create music that embody such an idea-and it is at this juncture that music becomes a kind of script. The composer follows an unspoken guidance, and this is reflected in the interactions between musicians during performance (Cook, 2013).

To clarify the concept, Cook gives the following elaboration:

A more contemporary perspective from which to think of scores as scripting social action is that of management theory. Effective management means designing frameworks within which people can work together. On the one hand this requires a clear goal that motivates and coordinates people's efforts. On the other, it means not unnecessarily prescribing the details of what they should do. Excessive prescription demotivates and disempowers people, leading them to do things by the book. But real life is rarely like the book. That is why as many decisions as possible should be made on the ground, on the basis of local information, and in real time. Effective management, then, empowers people by harnessing their tacit knowledge and creativity. It encourages them to play by ear, while still singing from the same songsheet as their colleagues. (Cook, 2013, p. 265)

What we find in the above quotation is in a way apropos to the subject of this paper. The Marcos regime was a project that served the vision of those that were in power. However, as much as a great amount of control was exerted on people especially after the declaration of martial law on 
the $21^{\text {st }}$ of September, 1972, there was also inevitable leeway, spaces that were beyond control. If they are present within management contexts, I can see no reason why they cannot be present in an oppressive regime, and why creativity, which really has no bounds, can make good of such spaces.

Such spaces, I believe, make it possible for resistance to arise. This can certainly happen in the context of artistic work which does not have bounds. It is at this juncture that Foucault's ideas on resistance become relevant:

Points of resistance are present everywhere in the power network. Hence there is no single locus of great Refusal, no soul of revolt, source of all rebellions, or pure law of the revolutionary. Instead there is a plurality of resistances, each of them a special case: resistances that are possible, necessary, improbable; others that are spontaneous, savage, solitary, concerted, rampant, or violent; still others that are quick to compromise, interested, or sacrificial; by definition, they can only exist in the strategic field of power relations. (Foucault, 1978, pp. 95-96)

From the above quotation, it seems that entities of power are always at risk within the carceral system that Foucault envisioned. As much as there are many centers from which power is emanated, there are also spaces wherein revolt can happen. The famed thinker renders the idea as something almost uncontrollable-hence, I am inclined to think that such a view might allow for thinking that there was something revolutionary in the work that Tinio did.

Saying this, in my view, is not exoneration. I would like to think that having to resort to clarifying that my work is not exoneration is really the manifestation of a dominant binary structure-it's either one is with the team or not. I think this is problematic, and it is my view that it is something that Foucault does not seem to be the one way of change:

Are there no great radical ruptures, massive binary divisions, then? Occasionally, yes. But more often one is dealing with mobile and transitory points of resistance, producing cleavages in a society-that shift about, fracturing unities and effecting regroupings, furrowing across individuals themselves, cutting them up and remolding them, marking off irreducible regions in them, in their bodies and minds. Just as the network of power relations ends by forming a dense web that passes through apparatuses and institutions, without being exactly localized in them, so too the swarm of points of resistance traverses social stratifications and individual unities. And it is doubtless the strategic codification of these points of resistance that makes a revolution possible, somewhat similar to the way in which the state relies on the institutional integration of power relationships. (Foucault, 1978, p. 96)

What I will seek to do in this paper is to identify the script behind the selected translations of Tinio in the field of music. After this, I will identify possible places wherein the script, borrowing from Cook, might not have been followed. Identifying places wherein there might deviance, as previously mentioned, resonates with Foucault-there can be a multiplicity of points for resistance.

Signing the Council of Writers and Artists (COWA) manifesto, though problematic, might not be the end-all, be-all when it comes to assessing the role of artists' relationships to the Marcos 
regime.

\section{The Cold War, East and West, and Philippine Music}

The need to examine possible subversions of the Marcos regime's script is important considering possible implications in dealing with despotic administrations and global forms of control. Tinio's translation efforts were preceded by a tradition that critics have called both salinawit and saling awit. The art of translation in the context of Tagalog poetry is something that poet and critic Michael M. Coroza discusses thoroughly. He says that certain details, being untranslatable in a direct way, are adapted and calibrated in order to meet the requirements of both music and verbal substance.

A song from another country is a form of non-material culture taken by the translator. In the act of translating or changing of the lyrics of the song, the translator prioritizes the materiality of the culture he belongs to and to which he offers the translation. His attention is focused on the listeners of his translation, to the owners of the language he used in translation. On one hand, it may be thought that the original message of the song is put aside because it is not appropriate to the situation of the listener. In this event, there is emphasis on the universality of the melody or the music, and the being context-based of the lyrics of the song ${ }^{4}$. ("Ang Apat na Proseso ng Saling-Awit" [The Four Procedures of Song Translation], 2019, p. 23)

Coroza points out in an earlier scholarly work that the incompatibilities of languages provide an opportunity for creativity for Filipino writers and lyricists, just as it has for those who have preceded them.

Both significant part, and something that blossomed in the great period of oral literature in the Philippines, the translation of poems or lyrics of a popular or familiar tune or melody is an ancient practice. Even though it appears to be translation, it is not a direct translation of the original text. Because of the need to confront the limitations set by the inevitable differences between the source and end languages, the translator is more creative instead of being a simple copyist. Although it is not his intention to change the original-and it is because of the popularity of the original that he made a translation-there are times when his translation goes beyond the words' success in the language and culture from whence they came ${ }^{5}$. ("Ang Sining ng Saling-Awit" [The Art of Song Translation], 2009, p. 27-28)

As language is reflective of the culture in which it is embedded, I think it reasonable to assert that a culture might be seen to dominate over the other in the process of translation. This view is apropos to the Philippine context, which still copes with what might be its colonial burden and opportunity.

What complicates this situation, in fact, is the second factor that reinforces the need to examine the translation work of Tinio. Around the time that Tinio made his translations, the situation was both ripe for a closer look and appreciation of culture, and vulnerable to the machinations of the neoliberal economy as manifested during the cold war. 
6 | Pop Song Translations by Rolando Tinio as Script and Subversion of the Marcos Regime

Two Filipino musicians and teachers at the then University of the Philippines (UP) Conservatory of Music, Eliseo M. Pajaro and Jose M. Maceda, attended an East West Music conference in Tokyo, Japan in 1961. The purposes of the conference, envisioned first in 1957, may seem innocuous at first glance:

A mutual understanding of Eastern and Western musical systems is urgent. Most important of all, such mutual understanding may lead, it is hoped, to the formulation of a general aesthetic theory capable of encompassing without implications of inferiority or superiority both the Eastern and the Western musical traditions. It is a regrettable fact that while this type of universal rapprochement has been evolving in literature, painting, and sculpture, it has scarcely started in the field of music. What development there has been in this direction has been primarily historical and sociological in its emphasis and has rarely been based on direct musical confrontation. Among musicologists, historians, and artists-both the composers and the performers - there is a growing realization of the need to revaluate our experiences and our assumptions about the music of other cultures, to develop a more broadly inclusive outlook and, if possible, to evolve a terminology of aesthetics suitable for expressing the multiplicity of music's traditions in all their national and regional aspects, and also in their essential unity ${ }^{6}$. ("East-West Music Encounter," 1957, pp. 506507)

Even though it seems that fostering a greater sense of unity and collaboration is the purpose of the music encounter, the purposes are likely entangled with what was happening between the United States and the Soviet Union around that time. Nicolas Nabokov, who was a part of the pilot meeting for the East West encounter, was the secretary-general of the Congress for Cultural Freedom (CCF). The musicologist Harm Langenkamp writes about how the CCF is intended to move against anti-Communist efforts that the UNESCO is unable to address:

One of the principal fruits and beneficiaries of the political dynamics of the early Cold War that shaped America's national security bureaucracy as we know it today was the Congress for Cultural Freedom (CCF), an international organization of intellectuals (academics, politicians, writers, journalists, opinion-makers, artists, etc.) who were convinced that the Soviet Union was a force for the worse more than the United States ever could be. A longtime dream of a select company of self-defined anti-Stalinists and realized with the support of the CIA's channels of communication and funding, the CCF seems to be conceived as an alternative to the United Nations Educational, Scientific and Cultural Organization (UNESCO), which by the end of the 1940s clearly could not live up to the universalist aspirations from which it emerged in late 1946. Back then, confidence prevailed that the "long-lasting [international] cooperation" UNESCO aimed at could "release energies" that would "make the atom bomb look like a dried pea on a platter." Yet, by its very 'universal' constitution, the organization almost immediately became entangled in the Cold War tensions that divided what once had been "united nations." While failure of Western member states to embrace a Marxist-based view on culture and science precluded the participation of the Soviet Union in UNESCO (until 1954), Eastern European member states (Poland, Hungary, Czechoslovakia, and Yugoslavia) virtually blocked every effort at cultural and scholarly exchange out of suspicion for Western intentions. Worse, 
early 1947, intelligence officials alarmed President Truman of the appointment of known Communist sympathizers to sensitive positions within UNESCO and advised to take action to prevent the organization from turning into an instrument for Communist purposes. If UNESCO was to become an ideological tool, then it was to promote the American conception of universality, and not the Soviet one. (Langenkamp, 2014, p. 20)

The effects of this East West Music Encounter seem to have been significant in the case of Philippine music, as reflected in discussions borne out of it. Two leading figures of the UP Conservatory, Pajaro and the institution's second Filipino director, Ramon Tapales, seemed to have two divergent views. Tapales, who led the conservatory for almost two decades, envisioned a oneworld in which economic imbalances should be recalibrated. It is interesting to note that he was all for doing away with labels "East" and West," which might lead to questions of how he viewed national identity:

Perhaps the dropping completely of the general terms "Eastern Music" and "Western Music" is a good starter....

Only then will the element of sheer curiosity about how an Eastern man would fare or look (musically) playing Western music on the concert stage disappear. They must appear before the world as true musicians and nothing else. For certainly the figure that the Eastern musicians cut before the Western eyes as something of an adult "enfant prodige" is neither healthy nor fair. And this goes also for the Eastern peoples who regard any American or European gentleman donning the Japanese kimono and eating chopsticks as a rara avis of the 20th century. (Tapales, 1966a, p. 5)

This possibility of dispensing with certain identifications does not stop there. It should lead to the balancing out of resources for musicians and chances to network with nations that provide opportunities all over the world:

One reason for this imbalance or lopsidedness is that actually each Eastern country maintains an independent, direct relation with the West, while among themselves no relation at all exists. It is true that because of big differences in economic set-ups, urban development, educational systems and even climatic conditions in South-and-East Asian countries cultural relations among them become rather unbalanced and complicated. Japan, with so many great cities and with a climate and other conditions identical with those of Europe and America, is naturally more drawn to the West than to her sister countries in the East, in so far as organizational and promotional set-ups are concerned.

From the standpoint therefore of financial and other advantages, she has nothing to look forward to in maintaining and developing cultural relations in music with say, the Philippines, Indonesia, or Malaya. From outward appearances, it means more prestige and material gains to her if her contacts are with the great metropolises of the world. Yet, if the perspective in a program of cultural intercourse in the East is founded on a longview philosophy, one might start by considering that, as in Health and Education, an investment in culture and goodwill should be expected to give, in return, dividends in culture and understanding and not in money (Tapales, 1966b, p. 6). 
8 | Pop Song Translations by Rolando Tinio as Script and Subversion of the Marcos Regime

On the other hand, Pajaro insisted that music education be geared towards cultivating a sense of nationalism in students. This seems to be in contradiction to the idea of encouraging a one-world way of viewing identity:

Love of country springs from a love of one's own. Our young people should be made to grow in the consciousness that they have a music of their own, typically and truly Pilipino and capable of expressing their desires and aspirations. If one of our objectives in education is to make better Pilipinos of our children, we must begin to realize that we cannot accomplish this objective with the aid of foreign material. We have to rely entirely on our musical resources-our songs and folk dances-to accomplish this objective....

The situation in our own country is such that since we have so much foreign music at our disposal, we do not find it urgently necessary to focus our attention on the use of native material. In the words of Bela Bartok, the Hungarian nationalist composer: "The musical education in countries of younger cultures works completely against the development of a natural language. What is a natural enough phenomenon, the use of older and established but nevertheless foreign material for teaching, creates the real difficulty in the development of an intrinsically native style and expression. (Pajaro, 1966, p. 11)

Looking at the differences between the views of Pajaro and Tapales, one can see the tensive working of ideas that both seem to play with the idea of what it is to be a nation, and how economic processes are inevitably connected to such play. It is many years later that scholars would examine how this was part of the overarching cold war dynamics - which Tinio, less than a decade after the publication of the thoughts of Pajaro and Tapales in Musical Journal of the Philippines, confronted subversively through his translations.

\section{Tinio Before Theater at the Cultural Center}

Before becoming deeply involved with the work at Teatro Pilipino at the Cultural Center, Tinio was already immersed in the research and creative work related to Filipino culture. In my unpublished masteral thesis entitled Bagay Poetry, the Bagay Movement, and the Filipinization of the Ateneo de Manila, I wrote about Bagay poems, the first of which were published in October 1965, being rooted in the Tagalog poetry tradition of focusing on imagery, phenomenological philosophy, and the image-based poems in English (including translations) written during the modern period. Moreover, there is a palpable alienation in the personae of the poems, which is brought about the modernization of daily life, connected to American colonization (Vitug, 2017). One of the most important aspects of Bagay poetry is that it is not discursive. It truly is focused on the image. Moreover, Lumbera insists that Bagay is not a movement. Lumbera attests:

It's not right to attach the word "movement" to "Bagay" as if there was an organized movement to attract many writers to do what we were doing. The truth is there was not much organized action on the part of us writers who were putting out our poems in Inter View magazine (which died after the first issue) and the campus magazine, Heights. It is true that Rolando and I planned to prepare a manifesto like the one that rebel poets in Europe did at the beginning of the $20^{\text {th }}$ century. The "proclamation" that I prepared was not published because, according to Rolando, critics might crucify us based on the 
principles that we presented in our "manifesto," thereby limiting our individuality as writers. In the end, the effect of the "Bagay" poems is the transfer to a few young campus writers of the consciousness that the primary role of the poet is to create "concrete" poems (like things) instead of preaching or delivering speeches, which had become a tradition in Tagalog poetry ("Panimula" [Introduction], 2002, xiii).

It is in the claim that Bagay is not a movement that I respectfully disagree with Lumbera. He himself speaks of passing on the knowledge about writing such poems above. More than this, these writers, on their own, dynamically continued to create art, and it seems that the way they were compelled to do so came from the inspiration that came from the imagining and writing of the Bagay poems (Vitug, 2017). That said, I am inclined to think of how related this is to the poem that Tinio writes as an alternative to Lumbera's manifesto: "I tried, through a manifesto, to set down the characteristics of Bagay poetry as rules. Rolando said that so doing would imprison us, and anyone who would submit to the manifesto would lose freedom as an individual poet. Instead, he wrote a poem entitled "Bagay" 8 ("Ang Pagtulang Bagay" [Writing Bagay Poetry], 2005, pp. 136).

The poem "Bagay," which is literally about a thing within a field, has power even without saying anything. It in and of itself compels the reader to give it a name. I believe that it is in this silent space, before the object or thing, that a person is compelled to move dynamically. This in and of itself is movement-and thus I asserted that because of the element of dynamism in the poems that translated into inspired action by the poets, Bagay can be considered a social movement (Vitug, 2017).

From the above, I would like to assert two things: first, Tinio was not inclined to have himself boxed in by anything; and second, Tinio was acquainted with the dynamic possibilities in spaces wherein nothing is said directly. I would like to think that this perspective, which he takes from the study of Tagalog poetry and culture and from the creative work of Bagay poetry, is something that would be connected to his approach to work in relation to the Marcoses and the Cultural Center.

\section{A Perceivable Script}

I think it is not too distant to speak of the milieu of the early 1970s as related to the time in which the Bagay poems were written, the mid-60s. The tensions related to the Philippines' relationship with the United States of America were very palpable, according to then Philippine Secretary of Public Information Francisco Tatad. It begs saying that the current deplorable problem of putting leftist ideas in a negative light was also already present then:

In Southeast Asia, where we have made the five-power Association of Southeast Asian Nations a viable regional organization in ten years, we have been able to cut across barriers of ideology in working out beneficient bilateral relations with the old and new communist regimes. Despite the present difficulties of some of our neighbors, it will be seen that the danger they face from beyond their borders is not much more grave or more immediate than the threat arising out of the internal weaknesses of their societies and governments.

But while this remains generally valid for the region, there is the danger that the continued 
maintenance of foreign military hardware in enormous quantities in our national territory, of installations and facilities that constitute or help to convey a nuclear peril to others, will be interpreted by Marxist governments in the area as an attempt to prolong or resurrect the regional presence of the power that lost the war in Vietnam. Such continued presence would constitute in their view a provocation, the implications of which we cannot afford to ignore. (Tatad, 1978, p. 85)

It is because of this that Tatad seems to be interested in the arts-because of its capacity to bridge nations and their interests. Indeed, art has a part to play in the work of cultural diplomacy for him:

Where the nations can find the way to an earnest exchange of the riches of their cultureof their achievements in the arts, and the sciences-there is reason to hope that the present situation will be propitious for both peace and human progress. Where the will to collaborate is lacking or stifled by the defense of privilege and dominance, there is likely to arise new conflicts that will deepen the current disequilibrium in the world. (Tatad, 1978, p. 106)

Although it might seem the best approach to begin this discussion with the speech of the powers that be-the Marcoses themselves-I think it might be prudent to begin with the spokesperson who finds himself, so to speak, interpreting and making sense of various utterances from his bosses. And indeed, what we find is a set of mixed messages about the arts-how valuable it is to culture, but what really matters is how this culture figures in the diplomacy necessary to forge beneficial international relations.

Moreover, it is good to contrast the above picture with analyses that show other aspects of the government during that time. As much as there is an attempt to look good through the support of the arts, and their potential benefit to international relations, there are also shady dealings that happen beneath the surface. This is most clearly seen in the situation of farmers in the early 1970s, during the same period:

This debate reflects the tension between proponents of agrarian reform and those who oppose it. Covering only rice and corn made Marcos' agrarian reform vulnerable to criticisms that the real intent was to target oligarchs but at the same time protecting cronies such as Benedicto, Cojuangco, Enrile, Lobregat etc. For one, Marcos' main opponent, Ninoy Aquino, and the Cojuangco clan, had interests not in rice but sugar. Also, rice and corn were essentially for domestic consumption and any shortfall may be augmented by imports. On the other hand, bananas, sugar, and coconuts were mainly for export and were top dollar earners. Because production of these crops required economies of scale, land reform would place production quotas at risk while rice and corn may be planted on small, individually titled lands without effect on the country's traditional export earnings. State intervention could then be focused only on support services-technology, irrigation, farm extension, and infrastructure to make the program viable. In short, land reform in rice and corn areas became feasible as these crops did not threaten foreign exchange receipts from the so-called cash crops (Kiunisala 19). (Mendoza, 2021, p. 136)

The above excerpt from a recent study shows that behind the Marcos Agrarian reform program of the 70s was a clear sign of crony capitalism, which is supposed to benefit a few. Indeed, one 
other aspect of the agrarian reform project was the fact that the suppliers of fertilizer for the rice and corn farmers covered by the program are from the United States (Mendoza, 2021).

Beyond the tension that is clear from the words of Tatad in the 1970s and in the assessment of Mendoza from the current day, are the words from the Marcoses themselves, who tried to keep the veneer of the mythical. It should be clear that the texts that they offer do not necessarily mask the need for cultural diplomacy that the Marcos administration engaged in. What is important is to mind the idea that this is part of the vision of order that they created.

Surely, the mythical proportions of the Imeldific vision are to be gleaned in these words uttered during the inauguration of the Cultural Center:

Reason and circumstance demand that this sanctuary should be built now, when the spirit of our young nation is first being tried and tested. For no one need remind us that from ancient times, the flowering of ideas and culture served to stimulate the economic and political destiny of a country; that it is not during times of luxurious ease and plenty that art is achieved or its inspiration most needed. How often Michelangelo would drop his chisel or his brush to go out to the walls of Florence and defend that beautiful and beloved Golden city." (Marcos, Imelda, 1973, p. 14)

And a few years later, the president himself would affirm the mythical quality by giving the First Lady a character to play-that of a powerful sorceress:

Surrounded by all this beauty, both natural and human, who can say where dream ends and reality begins? I can only fall back on Prospero's words, that "we are such stuff as dreams are made of."

Before all this art and necromancy, one conclusion is inescapable: The First Lady has the sorceress' gift of making dream into reality and reality into a dream. What poor mortal can cope with that? It is an enviable position, albeit a terrifying one, for a man to be in. (Marcos, Ferdinand, 1976, p. 8)

\section{Tinio at the Cultural Center's Theater}

Tinio left the Ateneo de Manila in 1975 after a controversial incident-that of Lumbera's tenure not being honored after being jailed due to underground activities. What follows is work in relation to Philippine arts and culture. He becomes involved with Teatro Pilipino at the Cultural Center, and becomes part of the editorial board of Sagisag magazine, which is under the Department of Public Information then headed by Francisco Tatad.

In the first issue of the above magazine, Tinio puts out a critical essay, Panitikan Para sa Kaisahan ng Bayan ("Literature for the Unity of the Nation"). Unlike the usual critical essay in which the focus is on the building of the argumentation that is done polemically, this essay has a focus on imagery and a form of irony that goes beyond the limits of the polemical. This going beyond is seen in the way that the ironic phrasings border-and even go beyond-the personal.

A good part of the text is focused on the idea that the American colonization devised a way for us to lose our innate dignity through the work of education. This would result in our focus 
on the work of the inner life, and the lack of confidence and focus to confront new technological developments because we are lacking in connection to what is our own indigenous ways of looking at the world ("Panitikan Para sa Kaisahan ng Bayan," 1975, p.7).

It is in this light that what I find to be the most striking imagery in the essay shines through - that of the home:

It is the writers' responsibility to pull their countrymen towards new windows and doors. However, never ever get out of the house! Because it is also a divine mandate for them to be pulled by the many uneducated ones who are the treasurers of the inner life of the nation. In the pulling against each other one will witness the necessary forward movement-forward which is also backward, like that of a snake ${ }^{9}$. ("Panitikan Para sa Kaisahan ng Bayan," 1975, p. 58)

In the face of the script that can be gleaned from the words of the Marcoses and their press secretary, it is clear that Tinio is more clearly positioned against America. Even what has been learned towards one's advantage is seen in a different light, as something that is a tool for being controlled. I personally find it surprising that items like fertilizer and ships and weapons fall under the word that Tinio uses: teknolohiya (technology) ("Panitikan Para sa Kaisahan ng Bayan," 1975). However, he does utilize local culture by the excellent use of the language, and there is no direct indictment of the Marcoses.

Panitikan Para sa Kaisahan ng Bayan, thus, might be said to be an exemplification of what has already been seen in the Bagay poems: there is a refusal to be boxed in, and there is also a dynamic call to movement. What one is compelled to do is not explicitly stated, and yet one still hears it and is compelled. Perhaps, there is much reason for this kind of playfulness. The First Lady seems to be very controlling when it comes to her Cultural Center:

In the role of active chairman of the Cultural Center of the Philippines, Mrs. Imelda Romualdez Marcos espouses a personal involvement with the responsibility and graciousness of her office as First Lady of the Land. Under her personal leadership and prestige, cooperation and resurgence of culture in the country is assured from the community and the government. The role of the First Lady in promulgating a national cultural program for the Philippines is the ideal response to the critical cultural challenge which the country faces today. ("Program for the Inauguration," 1969, Members of the Board)

\section{Creativity and Innovation}

Despite what would have been a most challenging situation, it seemed that much ferment was happening at the Cultural Center. At the opening of the center in 1969, one of the events was a Dularawan (contraction of words meaning "drama" "song," and "picture;" Perez OSB, 1969, page insert), which was seen to be a new artistic form:

A dularawan is basically the presentation of Filipino myth and history in drama, poetry, music, dance and spectacle. In other words, it is total theater. It is radically new in the sense that it brings together for the first time various elements of indigenous Filipino culture in 
an integrated composition of grand scale. It is deeply traditional in the sense that it appears to be the logical outgrowth of the development that flowered in the moro-moro and continued to prosper in the Filipino zarzuela....

The first dularawan, Salakot na Ginto ${ }^{10}$.... developed from an idea, evolved by the First Lady herself, Mrs. Imelda Romualdez Marcos and it received the whole-hearted support of the CCP Board of Trustees.... This idea was to bring forth not only a new Filipino work but above all a new Filipino form. (Perez OSB, 1969, page insert)

Five years later, within the regular season of Teatro Pilipino, Tinio would continue the innovations by translating foreign songs into Filipino and having them performed on stage. The following are the programs for the two Pop Songs concerts, of which Celeste Legaspi was the vocalist while Willy Cruz was the accompanying artist on November 8, 1975 and March 9, 1976, respectively. Both are to be found in the curriculum vitae of Rolando Tinio:

Performed by Celeste Legaspi on November 8 at the CCP Little Theater with Willy Cruz, pianist:

"Tunay na tunay" ("So in love")—Cole Porter

"Bakit iisipin" ("What's the use of wond'ring?")—Richard Rodgers and Oscar Hammerstein II

"Kung siya'y sukat magbalik" ("If he walked into my life")—Jerry Herman

"Saan o kailan" ("Where or when")—Richard Rodgers and Lorenz Hart

"Kung sakall" ("If I loved you")—Richard Rodgers and Oscar Hammerstein II

"Pait" ("Polin")—A. Pakmutova and R. Rozhdestvensky

"Di ko mawarl" ("Sinyaya vechnost")—M. Magomaev and G. Kozlovsky

"Araw-araw na hiwaga"—V. Lyebedev and R. Rozhdestvensky

"Lamig" ("Zimnayaya lyubov")—A. Babadzhanian and R. Rozhdestvensky

"Manawagan ka" ("Pazavi minya")—A. Babadzhanian and R. Rozhdestvensky

"Ang kailangan pa'y magmahalan" ("What the world needs now")—Burt Bacharach and Hal David

"Awit sa Iyo" ("A Song for You")—Leon Russell

"Langit mo, ulap mo" ("Summer me, winter me")-Michel Legrand and Alan \& Marilyn Bergman

"Minsan" ("Sometimes")—Henry Mancini and Felice Mancini

"Akala'y di na darating" ("The trouble with hello is goodbye")—Dave Grusin and Alan \& Marilyn Bergman

"Madayang Pangarap" ("April Fools")—Burt Bacharach and Hal David

"Batang-isip" ("Pieces of Dreams")—Michel Legrand and Alan \& Marilyn Bergman 
"Nakanino ang buong buhay mo?" ("What are you doing the rest of your life?")-Michel Legrand and Alan \& Marilyn Bergman

"Irog ko" ("Loving you")—R. Rudolf and Minnie Ripperton

"Alaala'y aanhin?" ("The way we were")—Marvin Hamlisch and Alan \& Marilyn Bergman

Performed by Celeste Legaspi on March 9 at the CCP Little Theater with Willy Cruz, pianist:

"Habang nabubuhay" ("As long as he needs me")—Lionel Bart

"Palagi akong iibig" ("Whoever you are, I love you")—Burt Bacharach and Hal David

"Labis ang asap" ("Smoke gets in your eyes")—Jerome Kern and Otto Harbach

"Tag-araw" ("Summertime")—Geroge Gershwin and D. Bosse Howard

"Masamang hangin" ("Ill wind")—Harold Arlen and Ted Koehler

"Pag wala ka" ("Stormy weather")—Harold Arlen and Ted Koehler

"Kahit minsan" ("Maybe this time")—John Kanden asnd (sic) Fred Ebb

"Walang nagpapalit" ("A house is not a home")—Burt Bacharach and Hal David

"Ang puso ko'y parang kakanta" ("I feel a song")—Tony Camillo and Mary Sawyer

"Di ba" ("Feelings")—Morris Albert

"Pag-ulan at Lunes" ("Rainy days and Mondays")—Paul Williams and Roger Nichols

"Awit ng pagmamahal" ("Love song")—L. Duncan

"Ako'y bakyang-bakya" ("The lady is a tramp")—Richard Rodgers and Lorenz Hart

"Sa'n pa ba ibig magpunta?" ("Do you know where you're going to?")—M. Masser and G. Goffin

A number of these songs have been made available to listeners through a recording entitled "Celeste Volume 1," which was initially released as a long playing record (LP) in 1976. One of the songs that has stuck with me is "Ako'y Bakyang-Bakya," which is supposed to be a Filipino translation" of "The Lady is a Tramp" by Richard Rodgers III and Lorenz Hart.

Tinio, given that he would not be placed in a box, did a very creative translation of the text. What is most notable about this text is the contextual choices that Tinio made. In the table below are a portion from the Tinio translation, my translation of the former, and a part of the original lyrics of Lorenz Hart.

Table 1: Comparison of Lyrics Based on "The Lady is a Tramp"

\begin{tabular}{|l|l|l|}
\hline Tinio Translation & $\begin{array}{l}\text { My Translation of Tinio } \\
\text { Translation }\end{array}$ & Original Lyrics by Lorenz Hart \\
\hline Ang hilig ko'y butong pakwan, & I like salted squash seeds, & I've wined and dined on mulligan \\
\hline
\end{tabular}




\begin{tabular}{|c|c|c|}
\hline Ayoko ng pastilyas; & I don't like milk pastilles; & $\begin{array}{l}\text { stew } \\
\text { And never wished for turkey }\end{array}$ \\
\hline $\begin{array}{l}\text { Nagdyi-dyip ako miski saan, } \\
\text { Hangqang sa Dasmarinas }\end{array}$ & $\begin{array}{l}\text { I take the jeepney everywhere, } \\
\text { Even up to Dasmarinas }\end{array}$ & $\begin{array}{l}\text { As I hitched and hiked and drifted, } \\
\text { too } \\
\text { From Maine to Albuquerque }\end{array}$ \\
\hline Hindi ako lumalampas & I do not cross & Alas, I missed the Beaux Arts Ball \\
\hline Sa linya ng batas, & The line of the law, & And what is twice as sad \\
\hline $\begin{array}{l}\text { At wala akong namamaneho } \\
\text { Kahit na Harabas }\end{array}$ & $\begin{array}{l}\text { And I don't have anything to drive } \\
\text { even a Harabas }\end{array}$ & $\begin{array}{l}\text { I was never at a party where they } \\
\text { honored Noel Ca'ad }\end{array}$ \\
\hline $\begin{array}{l}\text { Nakahihilo ang maging sosyal, } \\
\text { Hanggang Luneta lang } \\
\text { namamasyal } \\
\text { (Tinio, 2005, "Ako'y Bakyang- } \\
\text { Bakya," third song in liner notes) }\end{array}$ & $\begin{array}{l}\text { It's dizzying to be in high social } \\
\text { circles, } \\
\text { I only take trips up to Luneta Park. }\end{array}$ & $\begin{array}{l}\text { But social circles spin too fast for } \\
\text { me } \\
\text { My hobohemia is the place to be } \\
\text { (Rodgers, R., Hart, L., 1937, "The } \\
\text { Lady is a Tramp") }\end{array}$ \\
\hline
\end{tabular}

It can be seen that concepts and things foreign to the Filipino sensibility were replaced smartly by Tinio. On the other hand, part of the Tinio translation also expressed sentiments that are clearly anti-American. I believe that what follows below exemplifies such sentiments since the excerpt touches on the English language and credit cards, both of which, I believe, were brought to us during the American occupation. Moreover, the idea of debt is related to the financial relationship between the Philippines and the United States, which was already seen in the agrarian reform example.

Table 2: Anti-American Details in Tinio's Translation of "The Lady is a Tramp"

\begin{tabular}{|l|l|}
\hline Tinio Translation & My Translation of Tinio Translation \\
\hline Ayaw ko ng palabas ng Ingles & I don't like movies in English \\
O mag-isportkar, masyado'ng bilis; & Or sportscars, they're too fast; \\
At mano nang magmukhang matanda, & And so what if I look old, \\
Di ba't ako'y bakyang-bakya & Am I not common folk \\
& \\
Di ko alam ang magkredit-kard, & I don't know how to use credit cards, \\
Ang pera ko, aking lahat; & My money is all mine; \\
Sa kama ko, mag-isang hihiga, & I'll lie alone on my bed, \\
Kitams Ako'y (sic) bakyang-bakya & See! I'm really common folk \\
(Tinio, "Ako'y Bakyang-Bakya," third song in liner & \\
notes) & \\
\hline
\end{tabular}

I don't think it is coincidental that advertising man and songwriter Nonoy Gallardo, husband of Celeste Legaspi, would speak about Tinio's influence on him in relation to a song that would be associated with anti-Marcos protest: Saranggola ni Pepe (Pepe's Kite). Says Gallardo ${ }^{12}$ : 
There was a political statement. It was also about colonialism. I worked on that imagery. That was the concept of the song. The activists, the idealists, they were Pepe. And "highflying" was about idealism. The old deaf man was Marcos. The change in the wind, it saysreality bites. It was deceptively simple. I had a rough melody in my mind while I was writing, that's why the lyrics fit," says Gallardo. (Arceo-Dumlao, 2017, p. 240)

I started writing songs after we got married. I was inspired by the translations that Rolando Tinio did. I thought, I could do that after all, the translations were good. The stories were beautiful, says Gallardo. (Arceo-Dumlao, 2017, p. 242)

\section{Tinio Beyond Marcos}

As mentioned earlier in this paper, what might put Tinio in a negative light might be his signing of the COWA declaration of support for the Marcos-Tolentino tandem in 1986. However, in addition to what I have already discussed above, I think that a major thing that needs to be considered is the continued support and working relationship that Tinio got from people who were very explicitly against the Marcos administration. One such person was another National Artist, Nick Joaquin.

Nick Joaquin, unlike Tinio, could publicly put the First Lady to shame. If the president had flattered her by calling her a sorceress during the opening of the National Arts Center in 1976, Joaquin called her a "sensual enchantress" in front of the crowd:

Unless you are a virile spirit, do not dare to fall in love with art. For art must be mastered, or she will consume you; art must be used for more than delight, or, one dark of the moon, you will find her faery palaces gone and yourself wandering out in the cold and out of your wits. Let this be a warning to all you young people who mean to dedicate yourselves to the service of art. To regard art as merely the worship of the beautiful, with no moral or social concern, is to turn art into a mere sensual enchantress, and the world of art into a mere Cloud-Cuckoo-Land-which is what this mountain, and what this house of art we inaugurate today on this mountain, must never be. ("Art: a lovely, but dangerous mistress," 1976, p. 6)

It is also known that Joaquin only decided to accept the National Artist award in 1976 in order to help in the freeing of younger journalist Jose "Pete" Lacaba, who was jailed during the martial law period (De Guzman, 2017).

The political stance of Joaquin was not only clear in his actuations. It was also in the text. In fact, the play Portrait of the Artist as Filipino, which Tinio would end up translating in 1997 at the former's request (Sicam, 2017, p. 176) was interpreted to be the bearer of anti-imperialist significations, according to the critic E. San Juan, Jr.

There is no doubt that Joaquin's implicit project here is to exorcise the demon of the cashnexus, vulgar materialism, or, in more exact terminology, the ideology and practices of comprador capitalism in a U.S. Colony, under the guise of indicting the selfish utilitarianism of Manolo and Pepang and lauding the defenseless charms of Candida and Paula. Put more simply, the dramatic action to generate inwardness and psychological depth in a 
world that ceaselessly flattens everything and reduces all qualitative differences into abstract, exchangeable equivalence-the dynamic of reification converts humans into objects and in turn fetishizes thought, institutions, feelings. But in the execution of this project, a series of ironies and paradoxes are generated that introduces an element of indeterminacy undermining the play's consistent thematic consistency. (San Juan, 2008, p. 145)

It is my view that Joaquin must have had some kind of understanding of the difficulties that both Tinio and he had to live through during the martial law years. However, I would also like to think that he must have seen more in Tinio-not simply the acting and directing talent, but also the capacity to work dynamically in constraining spaces, and thus contributing to the cause of criticism and freedom.

Tinio does not just translate, Joaquin may have thought. Tinio also does it in a way that he tacitly adds his own biting criticism of the colonial enterprise-something that could end up making addicts out of people. Observe the Tinio translation below:

Table 3: Tinio's Translation of an Excerpt from "A Portrait of an Artist as Filipino"

\begin{tabular}{|c|c|c|}
\hline Joaquin Original & Tinio Translation & My Translation of Tinio Translation \\
\hline $\begin{array}{l}\text { TONY (not really noticing her): } \\
\text { Yeah-and all those other } \\
\text { glamorous places over there. } \\
\text { Spain, Italy, South America...but I } \\
\text { wouldn't be going there just to } \\
\text { have fun-no, siree! This won't } \\
\text { be a punk whoopee party like } \\
\text { the last time. I'd really like to be } \\
\text { serious this time. I'd really study, } \\
\text { really get educated. And then } \\
\text { we'll see if I'm wrong about } \\
\text { what've got! } \\
\text { (Joaquin, 2017, p. 123) }\end{array}$ & $\begin{array}{l}\text { Sa Espanya, Italya, America del Sur... } \\
\text { Hindi lang ako maggagaranatsa- } \\
\text { Mag-aaral ako, } \\
\text { Sisinghot ng kultura. } \\
\text { ("Ang Larawan," 2017, p. 243) }\end{array}$ & $\begin{array}{l}\text { In Spain, Italy, South America... } \\
\text { I won't be just wasting my time- } \\
\text { I will study, } \\
\text { Snort culture. }\end{array}$ \\
\hline
\end{tabular}

\section{In the End}

While Tinio is known to have been averse to being boxed into manifestos, he did sign the COWA declaration of support. I would like to believe that the critical political climate plus the above aversion might cast doubt on the signed document. The affirmative view of Tinio by Lumbera and Nick Joaquin, who were both against the Marcos administration, might also speak for Tinio. Tinio's poetic inclination plus his views on literature and the nation also call us to revisit his ideas. The essay Panitikan Para sa Kaisahan ng Bayan contains a clear anti-imperialist statement-could this be taken as a contradiction of Marcosian politics? The above, though not exculpating Tinio for very clearly siding with the Marcos regime, might merit a revisit of his works without excessive indictment. At a time when we can all benefit from learning from others in order to cope with populist leaders and right-wing extremists, keeping an open mind where it can be opened will 
certainly help.

\section{Declaration of Conflict of Interests}

The author(s) declared no potential conflicts of interest.

\section{Funding}

No funding has been received for the publication of this article. It is published free of any charge.

\section{Endnotes}

${ }^{1}$ The National Artist award is the highest recognition given by the Philippine government to Filipino artists, specifically for the fields of Music, Dance, Theater, Visual Arts, Literature, Film, Broadcast Arts, and Architecture and Allied Arts. The award is merited by a significant body of work that is seen as a contribution to Philippine culture. For more information, please see https://ncca.gov.ph/about-culture-and-arts/cultureprofile/national-artists-of-the-philippines/

${ }^{2}$ in 1986, dictator Ferdinand Marcos ran in the snap elections against widow Corazon C. Aquino, known for being a key player in the People Power Revolution. Marcos's campaign came at the heels of a period of martial rule in which many Filipino lives were lost, and human rights violated. Marcos and his wife Imelda are known to have plundered Philippine coffers. Please take a look at the articles "Marcos vs Aquino, and past snap elections around the world" by Michael Bueza (https://www.rappler.com/newsbreak/iq/marcosaquino-past-snap-elections-world) and "Just how bad was corruption during the Marcos years?" by JC Punongbayan (https://www.rappler.com/voices/thought-leaders/analysis-just-how-bad-was-corruptionmarcos-years). You may also want to visit https://martiallawmuseum.ph

${ }^{3}$ Quotations in the body of the text were written by myself unless indicated.

Marahil ang pinakamatibay na monumentong dadakila kay Rolando bilang Pambansang Alagad ng Bayan ay ang kanyang natipong mga salin ng mga dula mula sa iba-ibang panaho ng teatro sa Kanluran, ang kanyang mga akdang isina-Tagalog, dinirehe, dinisenyo at inihanap ng mga kabataang manonood. Sa kasaysayan ng teatro sa Filipinas, tanging si Rolando lamang ang umako sa isang gawaing kung sa ibang kamay nasalalay ay tiyak na mangangailangan ng maraming tao at limpak-limpak na salapi. Iyan ang pagoorganisa ng Teatro Pilipino, ang pagbubuo ng repertoryo nito sa pamamagitan ng mga salin, ang pagsasanay sa pangkat ng mga aktor na bubuhay sa mga tauhang galing sa iba-ibang panahon at kultura, ang paghubog ng mga produksiyong tutugong sa mga kahingian ng mga indibidwal na dula, at ang pagsinop sa mga limitadong sangkap (badyet, aktor na may kanya-kanyang kutsi, kagamitang kung saansaan hahagilapin, atbp.). Sa ngayon ay hindi pa natitimbang nang walang-labis, walang kulang ang kabuuan ng ambag sa ating sining at kultura ng mga salin ni Rolando. Ang natitiyak pa lamang natin ay isang mayamang kaban ang repertoryo ng Teatro Pilipino ng mga akdang sa mga darating na panahon ay babalik-balikan ng mga bagong manlilikha sa teatro sa kanilang paghahanap ng mga dulang mapagaaralan, mapaghahasaan ng talino at magagamit na pambusog sa mga manonood na hihinging panooring tutugon sa kanilang mga pangangailangang edukasyonal, kultural, at espirituwal

${ }^{4}$ Ang awit na nagmumula sa ibang bayan ay di-materyal na kulturang tinatanggap ng tagasáling-awit. Sa paghahalaw o pagpapalít ng letra sa mga awit na ito, higit na isinasaalang-alang ng tagasáling-awit ang 
materyalidad ng kaniyang kulturang kinabibilangan at pinaghahandugan ng kaniyang sáling-awit. Nakatuon ang kaniyang pansin sa mga tagapakinig ng kaniyang sáling-awit, sa mga nag-aangkin ng kaniyang wikang ginagamit sa pagsasalin o pagleletra. Sa isang banda, maaari ring isipin na binabalewala ang orihinal na sinasabi ng kanta sapagkat hindi naman angkop sa sitwasyon ng nakikinig. At, sa pangyayaring ito, higit na nabibigyang-diin ang pagiging higit na unibersal ng melodiya o musika sa isang panig at ang pagiging nakabatay-sa-kultura ng letra ng awit sa kabiláng panig.

${ }^{5}$ Bahagi at lumago sa dakilang panahon ng tradisyong pabigkas sa Filipinas, sinaunang praktis na ang pagsasaling-awit o ang paglalapat ng tula o liriks sa isang popular o pamilyar na himig o melodiya. Bagaman anyo ito ng pagsasalin, hindi ito tuwirang salin ng orihinal na teksto. Bunga ng pakikipagbuno sa limitasyong itinatakda ng kaibhan sa kalikasan ng wikang mulaan at ng tunguhang wika, higit na malikhain sa halip na mangongopya lamang ang tagapagsaling-awit. Bagaman hindi niya layuning palitan ang orihinal, at totoo namang dahil sa popularidad ng orihinal kaya siya lumikha ng salin, may pagkakataong nahihigitan ng kaniyang saling-awit ang tinamong tagumpay ng orihinal sa wika at kulturang pinagsalinan.

${ }^{6}$ It is worth noting that Maceda, declared Philippine National Artist for Music in 1997, was a member of the Pilot Meeting from which the quoted report comes from ("East-West Encounter," 1957, p. 507).

7 Hindi wastong kabitan ng salitang "kilusan" ang "Bagay" na wari baga'y may organisadong pagkilos upang akitin ang maraming manunulat na tularan ang halimbawa namin. Ang totoo'y walang gaanong organisadong pagkilos kaming mga makatang nagpapalabas ng mga tula sa mga magasing Inter View (na namatay pagkalabas ng unang isyu) at sa magasing pangkampus na Heights. Totoo na binalak naming (sic) ni Rolando na maghanda ng isang "manipesto" gaya ng ginawa ng mga rebeldeng makata sa Europa nang magsisimula pa lamang ang Siglo 20. Hindi nalathala ang inihanda kong "proklamasyon" dahil, ayon kay Rolando, baka sa hinaharap ay ipako kami ng mga kritiko sa mga prinsipyong nakalahad sa "manipesto" at sa gayo'y limitahan ang aming indibidwalidad bilang manlilikha." Sa dakong huli, ang naging bisa ng mga tulang "Bagay" ay ang paglilipat sa ilang nakababatang makata sa kampus ng kamalayan na ang pangunahing tungkulin ng makta (sic) ay ang paglikha ng mga tulang "kongkreto" (parang bagay) sa halip na mangaral o magtalumpati, na naging tradisyon na sa panulaang Tagalog.

${ }^{8}$ T inangka ko noon sa isang manipesto na italang tila mga batas ang mga katangian ng pagtulang Bagay. Sabi ni Rolando, ikukuong niyan tayo at ang paiilalim diyan ay mawawalan ng laya bilang indibidwal na makata. Sa halip, kumatha siya ng isang tulang pinamagatan niyang 'Bagay.'

9 Tungkulin nga ng mga manunulat ang humila sa kanilang mga kalahi tungo sa mga bagong bintana at pintuan. Ngunit huwag na huwag lalabas ng bahay! Sapagkat atas ding banal ang magpahila sila sa nakararaming mangmang na tunay na ingat-yaman ng pambansang kalooban. Sa paghihilahang iyan masasaksihan ang nararapat na pagsulong, pagsulong na pag-atras din itulad ng sa ahas.

10 "Salakot" is a straw hat, and a traditional headgear of Filipinos. "Salakot na Ginto," therefore, would be headgear made of gold and in the shape of a straw hat.

11 The word "bakya" literally means "wooden clog." "Bakyang-bakya" implies being cheap, as well as belonging to a lower social class.

12 Merong political statement doon. It was also about colonialism. I worked on that imagery. That was the concept of the song. The activists, the idealists, sila si Pepe. And matayog ang lipad was about idealism.

The matandang bingi was Marcos. Nagbago ang ihip ng hangin, about reality bites. It was deceptively simple. I had a rough melody in my mind while I was writing kaya sukat ang lyrics," says Gallardo. I started writing songs after we got married. I was inspired by the translations that Rolando Tinio did. Naisip ko, puwede palang ganon, ang ganda ng mga translations. Ang ganda ng mga kuwento, says Gallardo. 


\section{References}

"Declaration of the Coalition of Writers and Artists for Freedom and Democracy." (1986, January). Bulletin Today, 11.

Arceo-Dumlao, T. (2017). Himig at Titik. A Tribute to OPM Songwriters.

Bueza, Michael (2015). "Marcos vs Aquino, and past snap elections around the world." Rappler. https://www.rappler.com/newsbreak/iq/marcos-aquino-past-snap-elections-world

Cook, N. (2013). Beyond the Score: Music as Performance. Oxford University Press.

Coroza, M. M. Ang Apat na Proseso ng Saling-Awit. Hasaan Journal, 5(1), 1-25. Hasaan-Journal-Tomo-V2019-p.1-25.pdf (ust.edu.ph)

---. Ang Sining ng Saling-awit: Kasaysayan, Proseso, at Pagpapahalaga. Language Acquisition Resource Center, San Diego State University.

De Guzman, L. E. P. (2017, May). Nick Joaquin in the Age of Fake News. Business World, https://www.bworldonline.com/nick-joaquin-in-the-age-of-fake-news/

"East-West Music Encounter. Report Pilot Meeting. April 24-28, 1957." In H. Langenkamp, Cosmopolitan Counterpoint: Overt and Covert Musical Warfare and Diplomacy in the Early Cold War, 1945-1961 (505-507). [Doctoral dissertation, Universiteit Utrecht.]

Foucault, M. (1978). The History of Sexuality. Volume 1: An Introduction. Translated by Robert Hurley. Random House, Inc.

Joaquin, N. (2017) "A Portrait of the Artist as Filipino: An Elegy in Three Scenes." In Ang Larawan: From Stage to Screen (pp. 15-170). Anvil Publishing.

---. (1976, April). "Art: a lovely, but dangerous mistress." Philippine Daily Express, 2, 6.

Langenkamp, H. (2014) Cosmopolitan Counterpoint: Overt and Covert Musical Warfare and Diplomacy in the Early Cold War, 1945-1961. [Doctoral dissertation, Universiteit Utrecht.]

Lumbera, B. (2005) "Ang Pagtulang Bagay: Paghulagpos sa 'Luma', Pagtakas sa 'Bago." In R. Torres-Yu

(Ed.), Bayan at Lipunan: Ang Kritisismo ni Bienvenido L. Lumbera (133-137). UST Publishing House.

---. (2002). "Panimula." In Balaybay: Mga Tulang Lunot at Manibalang (xi-xiv). Talingdao Press.

---. (c2014) "Si Tinio, Henyo ng Maraming Sining." In Paunang Salita: Pieces of a Teacher's Mind (165-173). Pambansang Komisyon para sa Kultura at Sining.

Marcos, F. E. (1976, April). "The Artist and the Social Dreamer." Philippine Daily Express, 8.

Marcos, I. R. (1973) "Sanctuary of the Filipino Soul." In I. Maramag (Ed.), The Compassionate Society and Other Selected Speeches of Imelda Romualdez Marcos (13-16). National Media Production Center, Republic of the Philippines.

Martial Law Museum. (n.d.) https://martiallawmuseum.ph

Mendoza, M. P. (2021). Marcos' Agrarian Reform: Promises, Contradictions, and Lessons. UNITAS Journal, 94(1), 127-165. http://unitasust.net/wp-content/uploads/2021/05/UNITAS-94-1-Mendoza-MarcosAgrarian-Reform.pdf

"Order of National Artists." (n.d) GOVPH. https://ncca.gov.ph/about-culture-and-arts/cultureprofile/national-artists-of-the-philippines/

Pajaro, E.M. (1966) "Nationalism in Music." Musical Journal of the Philippines 1(2), 7-11.

Perez, B. Ma. OSB. (1969) "What is a Dularawan?" [Page insert in program]. In Isang Dularawan: Salakot na Ginto. Cultural Center of the Philippines.

Program for the Inauguration of the Cultural Center of the Philippines. (1969). Cultural Center of the 
Philippines.

Punongbayan, JC. (2019) "Just how bad was corruption during the Marcos years?" Rappler.

https://www.rappler.com/voices/thought-leaders/analysis-just-how-bad-was-corruption-marcosyears

Rodgers, R., \& L. Hart. (1937) "The Lady is a Tramp." Genius. https://genius.com/Rodgers-and-hart-thelady-is-a-tramp-lyrics

San Juan, E. (2008). Subversions of Desire: Prolegomena to Nick Joaquin. UNITAS Journal, 88(2).

Sicam, E. L. (2017) "Last Conversation with a Master Director." In Ang Larawan: From Stage to Screen (172176). Anvil Publishing.

Tatad, F. (1978). "The Encounter of Cultures." In Prospects of the Filipino (105-115). Raya Books.

---. (1978). "The Meaning of the Bases." In Prospects of the Filipino (81-86). Raya Books.

Tan, C. (2018, January). In 1986, Filipino Writers and Artists Sold Out to a Dictator. Charles Tan, Medium, https://charlesatan.medium.com/in-1986-filipino-writers-and-artists-sold-out-to-a-dictatordffd9946e52d

Tapales, R. (1966b) "Let's Look at a Musical One-World." Musical Journal of the Philippines, 1(3), 6-7.

---. (1966a) "On Eastern Musicians Performing Western Music." Musical Journal of the Philippines, 1(2), 3-

6.

Tinio, R. S. (2005) "Ako'y Bakyang-Bakya." [Liner notes]. In Celeste Volume 1 [CD]. Vicor.

---. (2017). "ANG LARAWAN, The Musical." Based on an original three-act play by Nick Joaquin. In Ang Larawan: From Stage to Screen (185-275). Anvil Publishing.

---. (1975, May) "Panitikan Para sa Kaisahan ng Bayan." Sagisag Magazine 1(1), 6-7, 58.

Rodgers, R., \& Hart, L. (n.d.) "The Lady is a Tramp." Genius.com, https://genius.com/Rodgers-and-hart-thelady-is-a-tramp-lyrics

Vitug, N.R. (2017). Bagay Poems, the Bagay Movement, and the Filipinization of the Ateneo de Manila. [Masteral Thesis, Ateneo de Manila University.]

\section{Author's bio-note}

Niccolo Rocamora Vitug is a literature professor at the University of Santo Tomas, and an editorial staff member of the university's UNITAS Journal. He is also working on his doctorate at the University of the Philippines' College of Music. His collection of poetry in English, Enter Deeply, is forthcoming with the University of the Philippines Press. 